\title{
Ilona Švihlíková: Jak jsme se stali kolonií
}

Praha, Rybka Publishers 2015, 230 s.

Koncom minulého roka sa aj na pulty slovenských kníhkupectiev dostala nová kniha ekonómky s politologickým vzdelaním Ilony Švihlíkovej s provokujúcim názvom Jak jsme se stali kolonií. Napriek zvoleniu expresívne a trochu bulvárne znejúceho titulu, nejde o agitačný spis plný konšpiračných teórií, ale, o síce čitatel'sky ústretovú, predsa však len odbornými úvahami, ekonomickými údajmi a štatistikami naplnenú publikáciu, ktorá mapuje najmä ekonomickú cestu Československa a neskôr Česka od revolúcie po súčasnost'. Ked’že čast' tejto cesty malo Slovensko v rámci Československa s Českom spoločnú, a vývoj sa po rozdelení na Slovensku napriek rôznym štartovacím podmienkam, či inému priemyselnému charakteru krajiny, v základných bodoch, až tak vel'mi nelíšil, predstavuje spomínaná publikácia zaujímavý pohl'ad aj pre slovenského čitatel'a. Všetky postsocialistické krajiny sa začleňovali do svetovej ekonomiky poznačenej dominanciou nadnárodných spoločností a čoraz viac sa rozširujúcou globalizáciou, čo ich proces transformácie značne poznačilo. Publikácia je podnetná nielen z pohl'adu ekonomického rámca, o ktorý sa autorka opiera, ale aj z hl'adiska širších filozofickoideových smerovaní, pretože ako sama autorka konštatuje, koloniálne postavenie krajiny sa netýka len ekonomickej oblasti, ale aj politickej a myšlienkovej a navyše: „Ekonomiku ale nelze vytrhnout a izolovat, či dokonce povýšit nad ostatní součásti společenského systému, proto bude pozornost věnována i oblasti politiky a mezinárodních vztahů tam, kde to bude vhodné“ (s. 8).

Kniha je okrem úvodu a záveru členená do desiatich kapitol, vrátane Pojmoslovia. Ako autorka konštatuje, napriek zameraniu sa na čitatel’a bez špeciálnych ekonomických znalostí, sa v texte nezaobíde bez používania niektorých ekonomických termínov, ktoré v prvej kapitole približuje. Rovnakú úlohu často plnia poznámky pod čiarou, avšak napriek tomu autorkinej pozornosti niektoré nie bežne známe pojmy unikli a neponúka ich bližšie objasnenie, čo porozumenie textu pre neodborníkov v politickej ekonómii komplikuje.

V časti s názvom Centrálně plánovaná ekonomika - obecná charakteristika si autorka všíma vybrané momenty československého socializmu, pričom konštatuje výhodnú pozíciu krajiny v porovnaní s ostatnými členmi východného bloku, ktorá však podl'a jej názoru nebola využitá. Polemizuje s názorom, že pred revolúciou bolo všetko v ekonomickej oblasti zlé a snaží sa poskytnút' vyváženejší pohl'ad na stav krajiny pred rokom 1989. Ďalšia kapitola sa zameriava na ekonomické prostredie, do ktorého sa krajina snažila po revolúcii začlenit', pričom konštatuje, že integrácia bola silne a negatívne ovplyvnená tzv. Washingtonským konsenzom. Pre systém, do ktorého Československo vstupovalo bola charakteristická koncentrácia globálneho trhu s vel'kou mobilitou nadnárodných firiem fungujúcich v prepojených siet’ach. Rovnako vzrastal vplyv finančného sektoru na 
ekonomiku. Autorka konštatuje, že západnému modelu pád východného bloku vlastne „kúpil“ čas, poskytol trh pre výrobky, lacnú pracovnú silu a spolu s podhodnoteným kurzom a tlakom na vlády ohl’adom nižších daní umožnil d’alšiu expanziu globálneho kapitalizmu. Autorka relatívne podrobne predstavuje desat' pravidiel tvoriacich jadro Washingtonského konsenzu aj s načrtnutím problematických momentov a kapitolu završuje konštatovaním, že opatrenia konsenzu pomohli korporátnemu sektoru z vyspelých krajín a naopak transformujúce sa ekonomiky sa ocitli bez manévrovacieho priestoru.

Že to nie je jediná cesta transformácie upozorňuje Švihlíková pomocou príkladov iných krajín, konkrétne celú kapitolu venuje Číne a jej reformám a hned' d'alšiu možnostiam inštitucionálnej ekonómie, ktoré pri transformácii neboli dostatočne využité. Spätost' ekonomickej a politickej dimenzie tvorí dôležitý moment v kapitole Společné znaky transformačního procesu.

Najrozsiahlejšie kapitoly Česká ekonomická transformace a Aktuální stav české ekonomiky - východiská, poskytujú kritickú sondu do transformačného procesu. Autorka na rovinu konštatuje, že koloniálního systému nijak zvlášt' neliší. Jen bývalé koloniální státy nahradily nadnárodní korporace, které systematicky vyvíjejí sofistikovaný tlak na stát, umně vynalézají možnosti, jak se vyhýbat zdanění atd." (s. 95). V týchto kapitolách venuje pozornost’ napr. privatizácii, úlohe bánk, menovému kurzu, či politike národnej banky. Všíma si fenomény chudoby, strachu, bezdomovectva, nerovnosti aj nezamestnanosti. Kriticky sa stavia k eurozóne, ktorá podl’a jej názoru rozdiely medzi jednotlivými krajinami prehlbuje a je nástrojom ovládania, nie solidarity, pretože prospieva Nemecku na úkor štrukturálne slabších krajín. Postavenie Česka hodnotí ako politickú perifériu, bez definovaného národného záujmu, kde sa energia venuje okrajovým záležitostiam a hlbšie otázky sa ani nekladú, pretože krajina stojí mimo hlavných intelektuálnych debát. Za úlohu je tak považované nasledovanie upadajúceho hegemóna.

Predposledná kapitola sa venuje vývoju tzv. vyspelých krajín, ked’že ekonomiky sú tak poprepájané, že celosvetové trendy sa dotýkajú všetkých krajín. Vel'kou výzvou sa stáva najmä robotizácia a automatizácia, ktorá stále znižuje počet pracovných miest a ohrozenie, ktoré autorka pocit'uje v súvislosti s možnost'ou uzatvorenia zmluvy TTIP medzi USA a Európskou úniou.

Posledná kapitola sa snaží od popisu stavu, v ktorom sa ekonomika nachádza, prejst' $\mathrm{k}$ načrtnutiu istej vízie do budúcnosti a stratégie, ako sa $\mathrm{z}$ daného stavu, ktorý hodnotí ako výrazne nevýhodný, najrýchlejšie vymanit'. Navrhnuté opatrenia sú späté najmä s podporou rozvoja lokálnej ekonomiky, návratom a rozšírením družstiev, definovaním statkov so strategickým významom a hlavne s rozvíjaním kritického myslenia a otvorenej diskusie.

Recenzovaná publikácia prináša značne kritický pohl'ad na proces transformácie, aj ked' interpretuje rovnaké štatistické údaje, ak@ na aké čitatel' zvyknutý 
u iných ekonómov. Korupcia, disfunkčný štát, nedostatky privatizácie, odliv ziskov cez nadnárodné firmy a podobne, sú len niektoré momenty, ktorým autorka venuje pozornost'. Konštatuje, že napriek kritickému pohl'adu sa vykonalo aj mnoho dobrého, avšak ešte viac je potrebné urobit', čo platí pre slovenskú ekonomiku rovnako výstižne ako pre tú českú. Napriek pomerne vyhranenému názoru autorky a expresívnejšie zvolenému slovníku, je publikácia predstavujúca alternatívny pohl'ad na transformačný proces nepochybne zaujímavým a hodnotným príspevkom do celospoločenskej diskusie a nepôsobí bulvárne, či konšpiračne.

\section{Literatúra}

Švihlíková, I. (2015): Jak jsme se stali kolonií. Praha: Rybka Publishers.

\section{Mgr. Lenka Kocinová, PhD.}

Univerzita Konštantína Filozofa v Nitre

Filozofická fakulta

Katedra Filozofie

Hodžova 1

94974 Nitra

Slovenská republika

lkocinova@ukf.sk

\section{Dick Russell: The Life and Ideas of James Hillman: Vol. 1, The Making of a Psychologist}

New York, NY: Helios Press, 2013

James Hillman, founder of the archetypal (imaginal) psychology and according to some the most original post-Jungian thinker of the $20^{\text {th }}$ century, passed away in October 27, 2011. His death became an opportunity to summarize not only his thought but also the expansive character of post-Jungian and archetypal tradition. I say "tradition" because in Jung's times one could speak only about analytical psychology, Jung and his disciples or followers, but since late 1960s (also thanks to Hillman's remarkable contribution) the Jungian thought started expanding to various disciplines and ramify itself into different schools. Such expansion was repeatedly underscored by London analyst Andrew Samuels ${ }^{1}$ but was and still is also visible in works of such authors like Susan Rowland, Lawrence R. Alschuler, Roberto Gambini, David Tacey, Ann Belfort Ulanov, Michael Vannoy Adams,

\footnotetext{
${ }^{1}$ Jung and the Post-Jungians, London: Routledge \& Kegan Paul 1985; New Developments in post-Jungian Field, Young-Eisendrath \& Dawson 2008, pp. 1-15.
} 